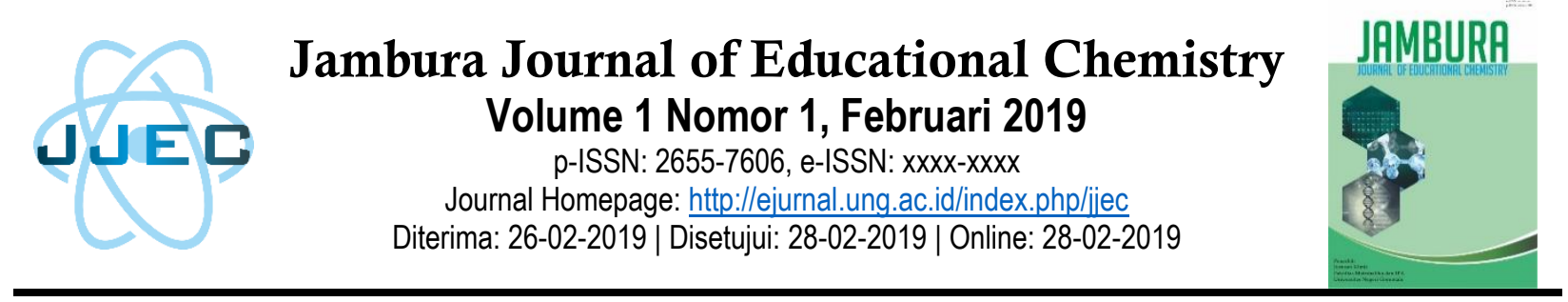

\title{
Deskripsi Pemahaman Mahasiswa Tentang Metabolit Sekunder dari Ekstrak Daun Jure Sebagai Insektisida Nabati Melalui Pembelajaran Berbasis Riset
}

\author{
Sitti Masita A. Pakaya1, Opir Rumape ${ }^{2}$, Wiwin Rewini Kunusa ${ }^{3}$ \\ 1,2,3Prodi Pendidikan Kimia, Jurusan Kimia, Fakultas Mamatika dan IPA, Universitas Negeri Gorontalo \\ e-mail: ${ }^{1}$ sitti 105053 S1Pend Kimia2013@mahasiswa.ung.ac.id
}

\begin{abstract}
Abstrak
Penelitian ini bertujuan untuk mengetahui metabolit sekunder dari ekstrak daun jure yang dapat digunakan sebagai insektisida nabati dan mendeskripsikan pemahaman mahasiswa tentang metabolit sekunder dari ekstrak daun jure sebagai insektisida nabati melalui pembelajaran berbasis riset. Metode yang digunakan yaitu eksperimen laboratorium yang dilakukan dalam beberapa tahap. Ekstraksi dilakukan dengan teknik maserasi dan fraksinasi, dilakukan uji fitokimia dan uji hayati fraksi-fraksi aktif pada larva kumbang kepik. Uji hayati fraksi-fraksi daun jure memberikan hasil aktivitas antimakan tertinggi terhadap larva kumbang kepik dengan pengamatan yang dilakukan selama $1 \times 24$ jam, ditemukan fraksi etil asetat pada variasi konsentrasi $10 \%$, yaitu memberikan nilai penghambatan makan sebesar $100 \%$ diikuti dengan fraksi metanol pada variasi konsentrasi $10 \%$ dengan nilai penghambatan makan sebesar $88,67 \%$ dan terakhir fraksi n-heksan $85,34 \%$ pada variasi konsentrasi $10 \%$. Untuk uji mortalitas larva kumbang kepik pengamatan dilakukan selama $1 \times 24$ jam menunjukkan bahwa tingkat mortalitas larva kumbang kepik dengan menggunakan fraksi etil asetat dengan konsentrasi $10 \%$ mencapai $66,67 \%$, untuk fraksi metanol dan n-heksan pada konsentrasi $10 \%$ menunjukkan tingkat kematian pada larva sebesar $60 \%$. Hasil penelitian yang didapat dalam eksperimen laboratorium digunakan dalam aplikasi pembelajaran berbasis riset yang dilakukan oleh mahasiswa. Hasil tes belajar mahasiswa menunjukkan hasil yang sangat memuaskan dengan 17 mahasiswa memperoleh ketuntasan dengan nilai 70,22 - 94,66 sedangkan 5 mahasiswa tidak tuntas dengan nilai 64,88-69,33.
\end{abstract}

Kata kunci: Daun jure, Insektisida Nabati, Antimakan, Mortalitas, Pembelajaran Berbasis Riset

\section{PENDAHULUAN}

Pendidikan kimia sebagai salah satu aspek pendidikan yang memiliki peranan penting dalam peningkatan mutu pendidikan, khusunya dalam menghasilkan sumber daya manusia (SDM) yang mampu berpikir kritis, kreatif dan mampu mengaplikasikan ilmu pengetahuan dalam kehidupan sehari-hari (Na'imah, 2010). Berbagai model pembelajaran dapat diterapkan dalam proses pembelajaran kimia secara kontekstual sehingga pembelajaran semakin menyenangkan dan mahasiswa dapat menemukan sendiri konsep yang dipelajari, salah satunya adalah model pembelajaran berbasis riset. Model pembelajaran berbasis riset memberi peluang/kesempatan kepada mahasiswa untuk mencari informasi, menyusun hipotesis, mengumpulkan data, menganalisis data, dan membuat kesimpulan atas data yang sudah tersusun, dalam aktivitas ini berlaku pembelajaran dengan pendekatan "learning by doing" (Widayati, 2010).

Mahasiswa S1 Program Studi Pendidikan Kimia Fakultas MIPA UNG khususnya untuk mahasiswa semester $\mathrm{V}$ harus memahami prinsip dasar dari pemisahan terhadap senyawa metabolit 
sekunder dari tumbuhan bahan alam dengan prinsip dasar metode yang sudah dipelajarinya.

Salah satu potensi bahan alam yang bermanfaat sebagai insektisida nabati adalah tumbuhan jure (Nerium oleander L.). Zibbu (2010) menyebutkan bahwa: tumbuhan ini digunakan sebagai racun tikus dan insektisida. Daun dan kulit kayu ditumbuk digunakan sebagai insektisida.Tumbuhan ini sendiri banyak diberkahi dengan berbagai macam molekul seperti vitamin, terpenoid, asam fenolik, lignin, stilbene, tanin, flavonoid, kuinon, kumarin, alkaloid, amina, betalain, dan metabolit lain yang kaya aktivitas aktioksidan (Biradar, 2013). Insektisida nabati dalam kurun waktu 20 tahun, memberikan perhatian sebagai pendekatan baru untuk pengendalian serangga (Isman, 2010). Hal ini untuk mengantisipasi berkembangnya penggunaan insektisida sintetik yang dinilai praktis oleh para petani untuk mencegah atau menghambat serangan hama yang ternyata berdampak negatif terhadap manusia dan lingkungan konsumen diantaranya adalah keracunan residu (sisa-sisa) pestisida/insektisida dalam produk pertanian yang digunakan. (Siahaya, 2014).

Berdasarkan data (Sutanto, 2002) penggunaan insektisida sintetik di Indonesia mencapai $70 \%$.Tidak adanya pengawasan dan peraturan yang tegas tentang penggunaan pestisida yang berlebihan, menimbulkan masalah yang sangat rumit dalam usaha menanggulangi serangan hama. Beberapa residu insektisida terdeteksi dalam jumlah berlebihan pada beberapa jenis bahan pangan, sayuran, buah-buahan, daging, ikan, dan lain-lain. Insektisida ternyata juga mematikan cukup banyak serangga bukan OPT (Organisme Pengganggu Tumbuhan), sehingga kemungkinan akan menimbulkan ledakan hama sekunder dan resurgensi hama (Sutanto, 2002). Menurut Sarwar (2015) bahwa: di seluruh dunia, kerugian ekonomi dan lingkungan utama karena untuk aplikasi pestisida, dampak pada kesehatan masyarakat, ternak dan produk ternak kerugiannya telah meningkat, biaya kontrol yang dihasilkan dari kerusakan yang berhubungan dengan pestisida merupakan musuh alami dan perkembangan resistensi pestisida hama. Untuk mengatasi hal ini ada solusi yang tepat untuk mengurangi penggunaan insektisida sintetik yaitu dengan menggunakan insektisida nabati yang ramah lingkungan dari berbagai tumbuhan bahan alam.

Berdasarkan uraian di atas penelitian ini bertujuan untuk mengkaji senyawa metabolit sekunder tumbuhan jure yang mudah di dapatkan sebagai insektisida nabati. Bahan yang digunakan yaitu bagian daunnya saja. Menurut (Isnawati, 2015) bagian tumbuhan jure yang dapat digunakan sebagai insektisida adalah akar, batang, kulit batang, daun dan bunga, tetapi yang paling sering digunakan adalah daunnya karena paling banyak mengandung oleandrin. Hal ini diharapkan dapat memberikan alternatif untuk dapat mengendalikan hama menggunakan insektisida nabati. Penelitian ini perlu dilakukan untuk mengevaluasi sejauh mana kemampuan mahasiswa dalam mengkorelasikan pemahaman yang telah didapatkan sebelumnya.

\section{METODE PENELITIAN}

\section{Isolasi Metabolit sekunder dari daun jure Lokasi dan Waktu Penelitian}

Penelitian ini dilaksanakan di Laboratorium

Kimia Universitas Negeri Gorontalo selama 7 bulan, dimulai pada bulan Februari-September 2017.

\section{Jenis Penelitian}

Penelitian ini menggunakan Rancangan Acak Lengkap (RAL) dengan enam perlakuan dan 3 kali ulangan. 1 kali faktorial dengan 3 kali pengulangan. Adapun susunan perlakuan untuk setiap ekstrak ditunjukkan pada Tabel 1

Tabel 1. Susunan Perlakuan Ekstrak Daun jure yang diaplikasikan untuk mengendalian Hama Larva Kumbang Kepik.

\begin{tabular}{cc}
\hline $\begin{array}{c}\text { Kode } \\
\text { Perlakuan }\end{array}$ & Konsentrasi Aplikasi \\
\hline No & Tanpa Aplikasi (0) \\
N1 & Ekstrak daun jure (1\%) \\
N2 & Ekstrak daun jure (2,5\%) \\
N3 & Ekstrak daun jure (5\%) \\
N4 & Ekstrak daun jure (7,5\%) \\
N5 & Ekstrak daun jure (10\%) \\
\hline
\end{tabular}




\section{Alat dan Bahan yang digunakan dalam penelitian \\ Alat}

Alat yang digunakan dalam penelitian ini antara lain: Satu set Alat Evaporator, satu set Alat Redestilasi, Blender Kering, Gelas Kimia, Corong kaca, Corong Pisah, Labu Takar, Spatula, Batang Pengaduk, Pipet Tetes, Toples Kaca, Ayakan, Loyang, Gunting, Keranjang, Kaca Arloji, Gelas Ukur, Neraca Analitik, , Botol Vial, Kertas saring. Bahan

Bahan yang digunakan dalam penelitian ini adalah tumbuhan jure yang dikumpulkan dari desa Botu Barani Kecamatan Kabila Bone Kabupaten Bone Bolango Provinsi Gorontalo.

\section{Bahan Kimia}

Bahan-bahan yang digunakan dalam penelitian ini antara lain: Metanol, Etil Asetat, NHeksana, Aquadest, $\mathrm{NaOH}, \mathrm{H}_{2} \mathrm{SO}_{4}$, serbuk $\mathrm{Mg}$, $\mathrm{HCl}, \mathrm{FeCl}_{3}$, Reagen Mayer, Reagen Dragendroff, Reagen Wagner, Reagen Lieberman-Bounchard, Vaselin, Batu didih, Tisu, Kapas, Aluminium Foil.

\section{Prosedur Kerja}

Prosedur kerja dalam penelitian ini meliputi beberapa tahap analisis yakni preparasi sampel, ekstraksi dan fraksinasi, uji fitokimia, uji antimakan, dan toksisitas terhadap hama.

\section{Preparasi Sampel}

Preparasi sampel dilakukan dengan cara mengumpulkan bagian daun yang sudah tua atau yang berwarna hijau tua. Sampel dibersihkan dengan cara dicuci dan dipotong kecil-kecil atau dirajang kemudian dikeringanginkan selama \pm 30 hari (proses pengeringan). Proses pengeringan pada suhu ruangan dengan tujuan tidak merusak komponen senyawa kimia yang terkandung dalam daun jure.

\section{Proses Ekstraksi dan Fraksinasi}

Pada tahap ekstraksi serbuk kasar daun jure sebanyak $600 \mathrm{~g}$ dimaserasi menggunakan pelarut metanol. Tahap maserasi dilakukan selama $5 \times 24$ jam, setiap 24 jam dilakukan penyaringan dan dimaserasi kembali dengan memakai metanol yang baru. Maserat yang diperoleh dipekatkan dengan cara dievaporasi menggunakan alat evaporator pada suhu $30-40^{\circ} \mathrm{C}$ diperoleh ekstrak kental metanol.
Tahap selanjutnya, melakukan fraksinasi dengan menimbang 50 gram ekstrak kental metanol disuspensi dengan metanol dan air dan dipartisi dengan pelarut $n$-heksan, diperoleh fraksi n-heksan dan fraksi air. Penambahan pelarut n-heksan kedalam fraksi air dilakukan berulang kali sampai fraksi $\mathrm{n}$ - heksan menjadi bening selanjutnya dievaporasi, menghasilkan ekstrak n-heksan. Fraksi air dipartisi dengan pelarut etil asetat diperoleh fraksi air dan fraksi etil asetat. Penambahan pelarut etil asetat kedalam fraksi air dilakukan berulang kali sampai fraksi etil asetat menjadi bening. Hasil partisi dari fraksi etil asetat dievaporasi pada suhu $30-45^{\circ} \mathrm{C}$ sampai diperoleh ekstrak etil asetat.

\section{Uji Fitokimia}

Uji fitokimia meliputi uji alkaloid, uji flavonoid, uji streoid, uji terpenoid, uji tanin, dan saponin.

\section{Uji Alkaloid}

Ekstrak kental sebanyak 0,1 gram dilarutkan dengan $10 \mathrm{~mL}$ metanol dan hasilnya dibagi dalam dua tabung reaksi. Tabung pertama diuji dengan pereaksi hager, tabung kedua ditambahkan $0,5 \mathrm{~mL} \mathrm{H}_{2} \mathrm{SO}_{4} 2 \mathrm{~N}$. Lapisan asam dipisahkan, dibagi dalam tiga tabung reaksi dan masing-masing tabung dilakukan pengujian dengan menggunakan pereaksi mayer, dragendrof, dan wagner. Jika terjadi endapan maka sampel adalah positif mengandung alkaloid.

\section{Uji Flavonoid}

Ekstrak kental sebanyak 0,1 gram dilarutkan dalam $10 \mathrm{~mL}$ metanol kemudian dibagi kedalam 4 tabung reaksi. Tabung pertama digunakan sebagai tabung kontrol, tabung kedua, ketiga, dan keempat berturut-turut ditambahkan $\mathrm{NaOH}, \mathrm{H}_{2} \mathrm{SO}_{4}$ pekat, dan serbuk $\mathrm{Mg}-\mathrm{HCl}$ pekat. Perubahan warna yang dihasilkan dari masngmasing tabung akan dibandingkan dengan tabung kontrol. Jika warna dari tiap tabung perlakuan terjadi perbedaan warna atau warna dari tabung kontrol tidak sama dengan tabung perlakuan maka sampel tersebut positif mengandung flavonoid.

\section{Uji Terpenoid dan Uji Steroid}

Identifikasi terpenoid dan steroid dilakukan dengan melarutkan ekstrak dalam 0,5 mL kloroform, kemudian menambahkan pereaksi 
Liebermann- burchard. Jika terjadi warna hijau kebiruan menunjukkan adanya steroid, warna merah kecoklatan menunjukkan adanya terpenoid. Uji Tanin

Identifikasi tanin dilakukan dengan melarutkan ekstrak kental dalam $10 \mathrm{~mL}$ aquades kemudian disaring dan filtrat ditambah dengan $\mathrm{FeCl}_{3} 1 \%$. Hasil positif ditandai dengan perubahan warna menjadi hiaju kehitaman.

\section{Uji Saponin}

Identifikasi saponin dilakukan dengan melarutkan ekstrak dalam $10 \mathrm{~mL}$ air panas kemudian dikocok kuat-kuat selama 10 detik. Hasil positif ditandai dengan timbulnya busa.

\section{Uji Antimakan dan Mortalitas Larva Kumbang} Kepik

Untuk menguji antimakan dan mortalitas larva kumbang kepik digunakan 45 cawan petri yang berisi daun kangkung pagar. Dengan 5 variasi perbandingan yaitu $1 \%, 2,5 \%, 5 \%, 7,5 \%$ dan $10 \%$. Masing-masing perlakuan diaplikasikan pada serangga secara non kontak. Aplikasi non kontak dilakukan dengan cara mengoleskan larutan uji yang telah siap pada permukaan daun kangkung pagar, kemudian diletakkan serangga diatas daun tersebut sebanyak 5 ekor. Perlakuan diulangi sebanyak 3 kali untuk masing - masing perlakukan dengan konsentrasi yang berbeda. Pengamatan dilakukan setiap hari (tiap 24 jam) setelah serangga dimasukkan. Dilihat seberapa besar efektifitas daun jure dalam mengendalikan serangga. Adapun rumus untuk menghitung aktivitas antimakan menurut Arivoli (2013) dan untuk persentase mortalitas larva menurut (Khairunnisa, 2014) dapat dihitung sebagai berikut:

Ket :

$$
\% \text { Antimakan }=\frac{\mathrm{K}-\mathrm{P}}{\mathrm{K}+\mathrm{P}} \times 100 \%
$$

$\mathrm{K}=$ daun yang dikonsumsi pada kontrol

$\mathrm{P}=$ daun yang dikonsumsi pada perlakuan

Ket :

$$
\% \text { Mortalitas }=\frac{\mathrm{a}}{\mathrm{a}+\mathrm{b}} \times 100 \%
$$

$\mathrm{a}=$ jumlah larva yang mati

$\mathrm{b}=$ jumlah larva yang hidup
Deskripsi Pemahaman Mahasiswa melalui Pembelajaran Berbasis Riset

Lokasi dan Waktu Penelitian

Penelitian pemahaman mahasiswa melalui pembelajaran berbasis riset dilaksanakan di Jurusan Kimia Universitas Negeri Gorontalo. Penelitian dimulai pada bulan September 2017.

\section{Pendekatan dan Jenis Penelitian}

Pendekatan yang digunakan dalam penulisan adalah metode deskriptif kualitatif. Deskripsi yang akan diangkat dalam penelitian ini adalah Deskripsi Pemahaman Mahasiswa tentang Metabolit Sekunder dalam Daun Jure sebagai Insektisida Alami melalui Pembelajaran Berbasis Riset.

\section{Peran Peneliti}

Peran peneliti dalam penelitian kualitatif menurut Sugiyono (2014) adalah sebagai instrumen kunci. Peran peneliti dalam penelitian ini menetapkan fokus penelitian, memilih informan sebagai sumber data, melakukan pengumpulan data, menilai kualitas data, analisis data, menafsirkan data, dan membuat kesimpulan atas penemuannya.

\section{Data dan Sumber Data}

Data dan sumber data dari penelitian ini adalah mahasiswa semester $\mathrm{V}$ Jurusan Kimia Universitas Negeri Gorontalo. Sumber data dipilih secara purposive sampling atau pengambilan sampel bertujuan.

\section{Prosedur Pengumpulan Data}

Deskripsi pemahaman mahasiswa

Penelitian ini dilakukan 4 kali pertemuan, dimana 3 kali pertemuan dalam proses pembelajaran berbasis riset dan 1 kali pertemuan yaitu tes hasil belajar. Pemahaman mahasiswa diidentifikasi menggunakan tes essay sebagai instrumen penelitian. Tes essay berupa soal-soal yang memuat konsep dasar tentang pemisahan yang terdiri dari 8 butir soal yang memuat tingkat kongnitif $\mathrm{C} 1-\mathrm{C} 6$. Soal digunakan dalam penelitian ini telah diuji kevalidannya.

\section{Observasi}

Observasi dilakukan di Jurusan Kimia Universitas Negeri Gorontalo untuk mengamati keadaan lingkungan kampus dan fasilitas yang mendukung selama proses pembelajaran. Observasi 
ini bertujuan untuk mengetahui kemungkinan penyebab pemahaman mahasiswa.

\section{Dokumentasi}

Dokumentasi dilakukan untuk melihat dokumentasi nilai dan buku pegangan mahasiwa dalam pembelajaran kimia. Hal ini untuk mengetahui kemungkinan pemahaman yang diperoleh karena sumber belajar yang ada.

\section{Analisis Data}

Analisis data yang digunakan dalam penelitian ini yaitu analisis data deskriptif kualitatif. Data-data yang diperoleh dikelompokkan berdasarkan tes hasil belajar mahasiswa. Tes hasil belajar mahasiswa dinilai berdasarkan ketuntasan individual dan ketuntasan klasikal. Untuk menghitung presentasi dapat digunakan persamaan berikut (Purwanto, 2009):

\section{Tes Hasil Belajar}

Ketuntasan Individual $=\frac{\text { Jumlah skor yang diperoleh }}{\text { Skor maksimum }} \times 100$

Ketuntasan klasikal $=\frac{\text { Jumlah mhsiswa yg tuntas }}{\text { Jumlah seluruh mahasiswa }} \times 100$

\section{Pengecekan Keabsahan Data}

Pengecekan keabsahan data yang digunakan dalam penelitian ini dengan cara triangulasi teknik. Menurut (Sugiyono, 2014) triangulasi teknik digunakan untuk menguji keabsahan data yang dilakukan dengan cara mengecek data kepada sumber yang sama dengan teknik yang berbeda. Dalam penelitian ini setelah observasi dan dokumentasi dari mahasiswa Semester V program studi Pendidikan Kimia UNG dicek kembali dengan hasil tes essay.

\section{Tahap-tahap Penelitian}

Tahap-tahap penelitian secara umum dilakukan dalam tiga tahap yaitu tahap awal, tahap pelaksanaan dan tahap akhir. Untuk prosedur pelaksanaan proses pembelajaran berbasis riset diadaptasi dari model pembelajaran Blume, dkk (2015). Diagram penerapan Pembelajaran Berbasis Riset ditunjukkan pada Gambar 1.

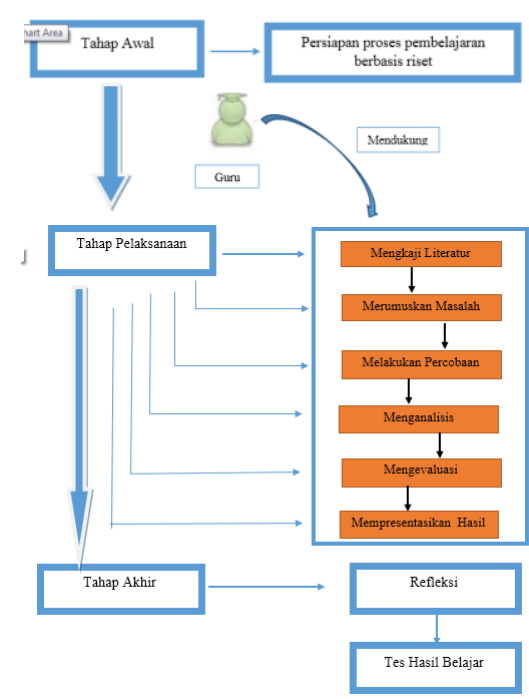

Gambar 1. Diagram Alir Penerapan Proses Pembelajaran Berbasis Riset

\section{HASIL DAN PEMBAHASAN}

\section{Isolasi Metabolit Sekunder dari Tumbuhan Jure Preparasi Sampel}

Preparasi sampel daun jure yang dirajang dengan ukuran kecil tujuannya adalah untuk memperluas permukaan partikel sehingga mempermudah pelarut untuk menembus dinding sel mengekstrak senyawa metabolit sekunder dalam sampel. Pada proses pengeringan sampel daun jure hanya dapat diangin- anginkan di ruangan yang terbuka sampai kering dengan tujuan agar komponen-komponen senyawa organik pada sampel daun jure tidak rusak.

\section{Ekstraksi dan Fraksinasi}

Ekstraksi adalah suatu cara untuk menarik komponen-komponen kimia yang terdapat dalam bahan simplisia. Jenis-jenis ekstraksi yang digunakan tergantung pada tekstur dan kandungan air bahan tumbuhan yang diekstraksi dan jenis dari senyawa yang akan diisolasi (Harborne, 1987). Proses maserasi dilakukan selama $5 \times 24$ jam dengan menggunakan pelarut metanol yang mampu mengikat semua komponen kimia yang terdapat dalam tumbuhan, baik yang berifat non polar, semipolar maupun polar. Maserat yang diperoleh diuapkan dengan menggunakan alat rotary evaporator pada suhu $30-40^{\circ} \mathrm{C}$. Ekstrak kental metanol tumbuhan jure yang diperoleh ditunjukkan pada Tabel 2 
Tabel 2. Hasil Ekstrak Kental Metanol.

\begin{tabular}{ccc}
\hline $\begin{array}{c}\text { Sampel kering } \\
(\mathbf{g})\end{array}$ & $\begin{array}{c}\text { Hasil ekstrak } \\
(\mathbf{g})\end{array}$ & Rendemen (\%) \\
\hline 600 & 131 & 21,83 \\
\hline
\end{tabular}

Berdasarkan Tabel 2 bahwa sebanyak 600 gram sampel kering yang diperoleh berasal dari sampel awal basah sebanyak 1,5 Kg. Setelah melalui tahap ekstraksi maka diperoleh hasil ekstrak sebanyak 131 gram dengan rendemen $21,83 \%$.

\section{Fraksinasi}

Fraksinasi dilakukan dengan menggunakan corong pisah dimana 50 gram ekstrak kental ditambahkan dengan $100 \mathrm{~mL}$ metanol dan $50 \mathrm{~mL}$ aquades dan dilakukan pengocokan. Untuk fraksi menggunakan pelarut n-heksan dan etil asetat. Hasil fraksi untuk setiap pelarut ditunjukkan pada Tabel 3.

Tabel 3. Hasil dari Berbagai Macam Fraksi

\begin{tabular}{cc}
\hline Pelarut & Hasil Fraksi \\
\hline$n$-heksana & 6,6405 \\
Etil asetat & 8,6817 \\
Metanol & 14,4087 \\
\hline
\end{tabular}

Berdasarkan Tabel 3 bahwa dari ekstrak kental metanol 50 gram yang difraksinasi hasil yang diperoleh untuk fraksi $n$-heksan sebesar 6,6405 gram, untuk fraksi etil asetat sebesar 8,6817 gram dan fraksi metanol sebesar 14,4087 gram.

\section{Uji Fitokimia}

Ekstrak kental metanol daun jure diuji fitokimia untuk melihat kandungan metabolit sekunder meliputi uji Flavonoid, uji alkaloid, uji steroid, uji terpenoid, saponin dan tanin. Hasil uji fitokimia ditunjukkan pada Tabel 4.

Berdasarkan Tabel 4 di atas, hasil uji skrining fitokimia tumbuhan jure memberikan hasil positif untuk lima senyawa metabolit sekunder antara lain flavonoid, alkaloid, terpenoid, saponin dan tanin. Untuk Steroid memberikan hasil yang negatif.

Tabel 4. Hasil Uji Skrining Fitokimia

\begin{tabular}{|c|c|c|c|}
\hline $\begin{array}{c}\text { Uji } \\
\text { Fitokimia }\end{array}$ & Pereaksi & $\begin{array}{c}\text { Hasil } \\
\text { Ujii }\end{array}$ & Keterangan \\
\hline \multirow{3}{*}{ Flavonoid } & $\mathrm{NaOH}$ & + & Jingga \\
\hline & $\mathrm{H}_{2} \mathrm{SO}_{4}$ & + & Kuning keruh \\
\hline & $\mathrm{HCl}-$ serbuk Mg & + & Jingga \\
\hline \multirow[t]{4}{*}{ Alkaloid } & Mayer & + & Terdapat endapan putih \\
\hline & Hager & + & Terdapat endapan putih \\
\hline & Wagner & + & Terdapat endapan merah \\
\hline & Dragendroff & + & Terdapat endapan jingga \\
\hline Steroid & Lieberman-Bounchard & - & Tidak terbentuk warna hijau kebiruan \\
\hline Terpenoid & Lieberman-Bounchard & + & Merah kecokelatan \\
\hline Saponin & Aquades Panas & + & Terbentuk busa \\
\hline Tanin & $\mathrm{FeCl}_{3}$ & + & Hijau kehitaman \\
\hline
\end{tabular}

Uji Antimakan dan Mortalitas Larva Kumbang Kepik

\section{Uji Aktivitas Antimakan}

Senyawa antimakan merupakan suatu senyawa organik bahan alam yang sangat dibutuhkan oleh berbagai tanaman untuk melindungi dirinya dari serangan hama, baik serangga maupun mikroba serta organisme lain. Adapun hasil uji antimakan larva kumbang kepik setelah perlakuan berbagai tingkat konsentrasi ekstrak daun jure menggunakan fraksi metanol, etil asetat dan N-Heksan selama 24 jam ditunjukkan pada Tabel 5 
Tabel 5. Uji Antimakan Larva Kumbang Kepik setelah Perlakuan Berbagai Tingkat Konsentrasi Ekstrak Daun Jure Selama 24 jam

\begin{tabular}{|c|c|c|c|c|c|c|c|c|c|c|c|}
\hline \multirow{2}{*}{ Ekstrak } & \multirow{2}{*}{$\begin{array}{c}\text { Konsentrasi } \\
\text { Larutan Uji (\%) }\end{array}$} & \multicolumn{3}{|c|}{ Ulangan 1} & \multicolumn{3}{|c|}{ Ulangan 2} & \multicolumn{3}{|c|}{ Ulangan 3} & \multirow{2}{*}{$\begin{array}{c}\text { Rata-rata } \\
\text { Keaktifan } \\
(\%)\end{array}$} \\
\hline & & $\mathrm{K}$ & $\mathrm{P}$ & $\%$ & $\mathrm{~K}$ & $\mathrm{P}$ & $\%$ & $\mathrm{~K}$ & $\mathrm{P}$ & $\%$ & \\
\hline \multirow{5}{*}{ Metanol } & 1 & 13 & 3 & 62.5 & 12 & 3 & 60 & 10 & 3 & 53.84 & 58.78 \\
\hline & 2.5 & 17 & 4 & 61.90 & 10 & 2 & 66.66 & 14 & 3 & 64.70 & 64.42 \\
\hline & 5 & 16 & 3 & 68.42 & 1 & 0 & 100 & 12 & 1 & 84.61 & 84.34 \\
\hline & 7.50 & 17 & 3 & 70 & 7 & 0 & 100 & 13 & 1 & 85.71 & 85.23 \\
\hline & 10 & 16 & 2 & 77.77 & 16 & 0 & 100 & 16 & 1 & 88.23 & 88.67 \\
\hline \multirow{5}{*}{ Etil Asetat } & 1 & 13 & 2 & 73.33 & 12 & 4 & 50 & 10 & 2 & 66.66 & 63.33 \\
\hline & 2.50 & 9 & 1 & 80 & 7 & 1 & 75 & 10 & 2 & 66.66 & 73.88 \\
\hline & 5 & 13 & 2 & 73.33 & 10 & 1 & 81.81 & 12 & 2 & 71.42 & 75.52 \\
\hline & 7.50 & 6 & 0 & 100 & 8 & 0 & 100 & 9 & 0 & 100 & 100 \\
\hline & 10 & 6 & 0 & 100 & 4 & 0 & 100 & 5 & 0 & 100 & 100 \\
\hline \multirow{5}{*}{ n-Heksan } & 1 & 9 & 3 & 50 & 11 & 3 & 57.14 & 13 & 4 & 52.94 & 53.36 \\
\hline & 2.50 & 9 & 2 & 63.63 & 8 & 2 & 60 & 10 & 2 & 66.66 & 63.43 \\
\hline & 5 & 9 & 3 & 50 & 7 & 1 & 75 & 9 & 1 & 80 & 68.33 \\
\hline & 7.50 & 7 & 2 & 55.55 & 16 & 1 & 88.23 & 10 & 1 & 81.81 & 75.20 \\
\hline & 10 & 1 & 0 & 100 & 6 & 1 & 71.42 & 12 & 1 & 84.61 & 85.34 \\
\hline
\end{tabular}

Berdasarkan Tabel 5 di atas, untuk masingmasing ekstrak metanol, etil asetat dan n-heksan dengan berbagai konsentrasi larutan uji menunjukkan peningkatan keaktifan seiring dengan peningkatan konsentrasi larutan uji.

Mortalitas Larva Kumbang Kepik

Mortalitas dapat didefiniskan sebagai ukuran jumlah kematian karena akibat yang spesifik pada

Table 6. Uji Mortalitas Kumbang Kepik Setelah Perlakuan Berbagai Tingkat Konsentrasi Ekstrak Daun Jure Selama 24 Jam.

\begin{tabular}{|c|c|c|c|c|c|c|c|c|c|c|c|}
\hline \multirow[b]{2}{*}{ Ekstrak } & \multirow{2}{*}{$\begin{array}{c}\text { Konsentrasi } \\
\text { Larutan }(\%)\end{array}$} & \multicolumn{3}{|c|}{ Perlakuan 1} & \multicolumn{3}{|c|}{ Perlakuan 2} & \multicolumn{3}{|c|}{ Perlakuan 3} & \multirow{2}{*}{$\begin{array}{c}\text { Rata-rata } \\
\text { Mortalitas (\%) }\end{array}$} \\
\hline & & $\mathrm{a}$ & $\mathrm{b}$ & $\%$ & $\mathrm{a}$ & $\mathrm{b}$ & $\%$ & a & $\mathrm{b}$ & $\%$ & \\
\hline \multirow{5}{*}{ Metanol } & 1 & 1 & 4 & 20 & 1 & 4 & 20 & 1 & 4 & 20 & 20 \\
\hline & 2.50 & 1 & 4 & 20 & 1 & 4 & 20 & 1 & 4 & 20 & 20 \\
\hline & 5 & 2 & 3 & 40 & 2 & 3 & 40 & 2 & 3 & 40 & 40 \\
\hline & 7.50 & 2 & 3 & 40 & 3 & 2 & 60 & 3 & 2 & 60 & 53.33 \\
\hline & 10 & 3 & 2 & 60 & 3 & 2 & 60 & 3 & 2 & 60 & 60 \\
\hline \multirow{5}{*}{ Etil Asetat } & 1 & 1 & 4 & 20 & 1 & 4 & 20 & 1 & 4 & 20 & 20 \\
\hline & 2.50 & 1 & 4 & 20 & 1 & 4 & 20 & 1 & 4 & 20 & 20 \\
\hline & 5 & 1 & 4 & 20 & 2 & 3 & 40 & 2 & 3 & 40 & 33.33 \\
\hline & 7.50 & 2 & 3 & 40 & 2 & 3 & 40 & 3 & 2 & 60 & 46.66 \\
\hline & 10 & 3 & 2 & 60 & 3 & 2 & 60 & 4 & 1 & 80 & 66.66 \\
\hline \multirow{5}{*}{ N-Heksan } & 1 & 1 & 4 & 20 & 2 & 3 & 40 & 2 & 3 & 40 & 33.33 \\
\hline & 2.50 & 1 & 4 & 20 & 2 & 3 & 40 & 2 & 3 & 40 & 33.33 \\
\hline & 5 & 3 & 2 & 60 & 2 & 3 & 40 & 2 & 3 & 40 & 46.66 \\
\hline & 7.50 & 3 & 2 & 60 & 3 & 2 & 60 & 3 & 2 & 60 & 60 \\
\hline & 10 & 3 & 2 & 60 & 3 & 2 & 60 & 3 & 2 & 60 & 60 \\
\hline
\end{tabular}

suatu populasi. Dalam hal ini kematian yang terjadi pada saat penelitian berlangsung.

Adapun mortalitas larva kumbang kepik setelah perlakuan berbagai tingkat konsentrasi ekstrak daun jure selama 24 jam ditunjukkan pada Tabel 6 
Berdasarkan Tabel 6 untuk masing-masing ekstrak metanol, etil asetat dan n-heksan sama-sama memperoleh tingkat mortalitas larva pada persentase $60 \%$ untuk ekstrak metanol dan $\mathrm{N}$ Heksan sedangkan untuk ekstrak etil asetat memperoleh $66,67 \%$. Adapun persentase tingkat mortalitas larva kumbang kepik setelah perlakuan berbagai tingkat konsentrasi ekstrak daun jure selama 24 jam ditunjukkan pada Gambar 2

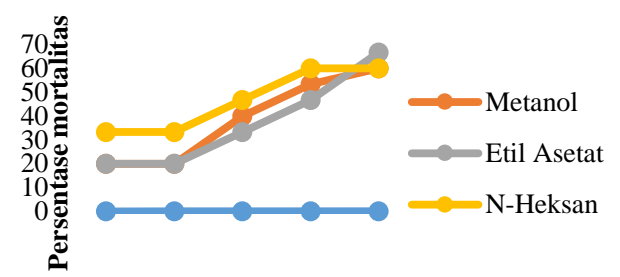

Gambar 2. Grafik mortalitas larva kumbang kepik setelah perlakuan berbagai tingkat konsentrasi ekstrak daun jure selama $24 \mathrm{jam}$.

Berdasarkan Gambar 2, Untuk setiap peningkatan konsentrasi tidak selalu diikuti dengan peningkatan mortalitas larva. Untuk fraksi metanol dan N-Heksan pada konsentrasi $10 \%$ tingkat mortalitas larva kumbang kepik dengan persentase capaian $60 \%$. Berbeda dengan Etil Asetat pada konsentrasi $10 \%$ menunujukkan persentase mortalitas larva dengan capaian $66,67 \%$. Dengan demikian, persentase mortalitas larva berbanding lurus dengan peningkatan konsentrasi.

Deskripsi Pemahaman Mahasiswa tentang Metabolit sekunder tumbuhan jure sebagai insektisida melalui Pembelajaran Berbasis Riset Hasil dan Pembahasan

Penerapan model pembelajaran berbasis riset dibuat dalam bentuk percobaan agar lebih mudah dalam memahami konsep secara menyeluruh dan mengkondisikan mahasiswa seperti melakukan penelitian secara langsung.

\section{Hasil Belajar}

Penelitian hasil belajar dievaluasi dengan menggunakan tes soal essay. Soal yang diberikan terdiri dari 8 butir soal yang tersusun berdasarkan tingkat kognitif C1-C6 dengan perolehan skor maksimum 70.

Ketuntasan individual adalah ketuntasan yang diperoleh secara individu/perorangan sedangkan ketuntasan klasikal adalah ketuntasan untuk seluruh mahasiswa.

\section{Ketuntasan Individual}

Ketuntasan ini diperoleh dengan cara membagi antara skor yang diperoleh mahasiswa dengan skor total. Adapun hasil belajar mahasiswa dalam bentuk ketuntasan individual ditunujukkan pada Gambar 3.

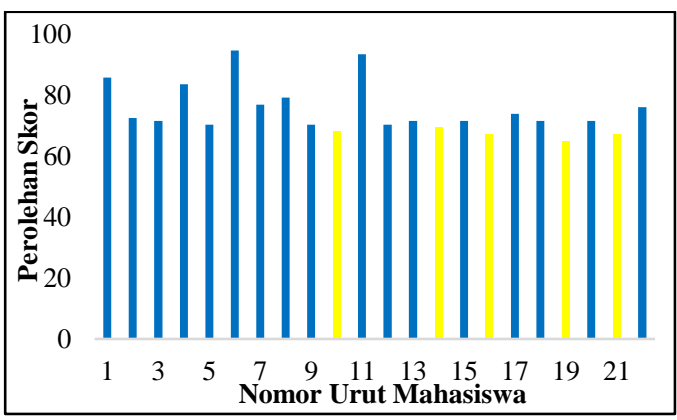

Gambar 3. Histrogram hasil belajar mahasiswa secara individual

Berdasarkan Gambar 3 di atas, mahasiswa yang memperoleh nilai tuntas sebanyak 17 mahasiswa dengan nilai 70,22-94,66 sedangkan nilai tidak tuntas terdapat 5 mahasiswa dengan nilai 64,88-69,33.

\section{Ketuntasan Klasikal}

Ketuntasan klasikal dapat dilihat dengan jumlah mahasiswa yang memperoleh ketuntasan dibagi dengan jumlah keseluruhan mahasiswa. Ketuntasan klasikal mahasiswa ditunjukkan pada Gambar 4

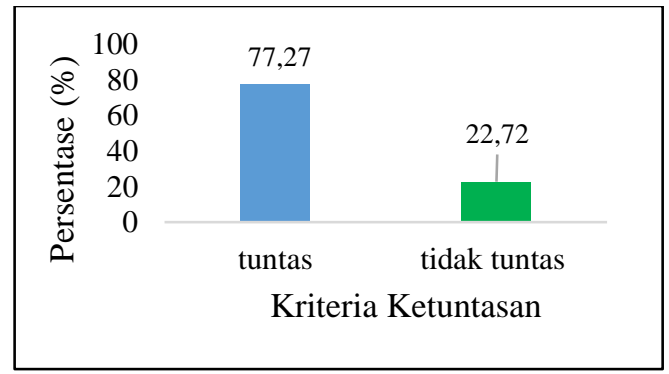

Gambar 4. Histogram hasil belajar mahasiswa secara klasikal.

Berdasarkan Gambar 4 di atas, mahasiswa kimia melalui pembelajaran berbasis riset dapat dikatakan sangat baik. Ketuntasan klasikal hingga mencapai 77,27\% dan $22.72 \%$ tidak tuntas.

Berdasarkan 8 butir soal essay yang diberikan, presentase capaian masing-masing soal terhadap 22 mahasiswa ditunjukkan pada Gambar 5 


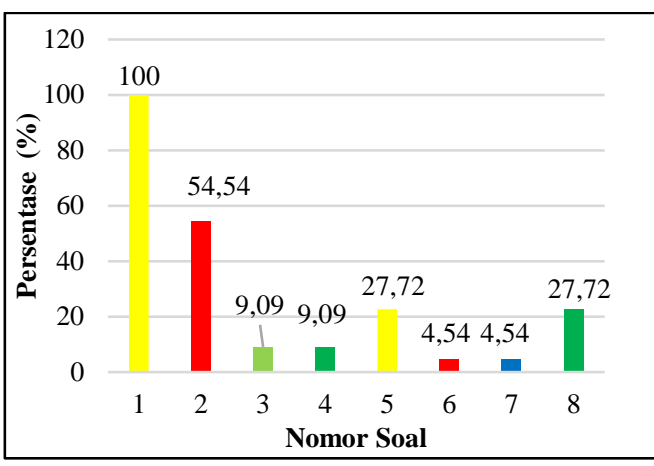

Gambar 5. Histogram persentase mahasiswa yang menjawab benar mencapai skor maksimal pada masing-masing soal

Berdasarkan Gambar 5 di atas, dari 22 mahasiswa yang menjawab dengan benar mencapai skor maksimal pada soal no 1 sebanyak 25 mahasiswa $(100 \%)$, soal nomor 2 sebanyak 12 mahasiswa $(54,54 \%)$, soal nomor 3 sebanyak 2 mahasiswa $(9,09 \%)$, soal nomor 4 sebanyak 2 mahasiswa $(9,09 \%)$, soal nomor 5 sebanyak 5 mahasiswa $(22,72 \%)$, soal nomor 6 sebanyak 1 mahasiswa $(4,54 \%)$, soal nomor 7 sebanyak 1 mahasiswa $(4,54 \%)$ dan soal nomor 8 sebanyak 5 mahasiswa (22,72\%). Sedangkan mahasiswa lainnya hanya mendapat skor sesuai capaian dalam mengisi jawaban dari soal yang diberikan.

Ada beberapa faktor yang membuat cara belajar tidak maksimal yang berdampak pada hasil belajar yang rendah. Menurut (Sudjana, 2011) tujuh puluh persen prestasi mahasiswa di kampus ditentukan oleh kemampuan diri mereka sendiri, sisanya oleh lingkungan. Faktor lingkungan juga sangat mempengaruhi karena lingkungan yang baik akan berdampak baik pula. Selain faktor lingkungan perlu juga mendisiplinkan cara belajar. Yeung, Read dan Schmid (2005), mengandaikan bahwa beberapa faktor yang mempengaruhi pembelajaran siswa. Contoh dari faktor-faktor seperti itu termasuk, namun tidak terbatas pada preferensi gaya belajar siswa, minat terhadap materi belajar dan lingkungan belajar (dalam Alade, 2014).

\section{PENUTUP}

Berdasarkan pembahasan di atas, dapat disimpulkan bahwa: (1) Ekstrak metanol daun jure dapat berperan sebagai insektisida nabati dengan persentase aktivitas antimakan larva kumbang kepik $88,67 \%$ untuk fraksi metanol, $100 \%$ untuk fraksi etil asetat dan 85,34\% untuk fraksi N-Heksan. Untuk tingkat mortalitas larva kumbang kepik masingmasing fraksi metanol dan N-Heksan mencapai $60 \%$ sedangkan untuk fraksi Etil Asetat mencapai 66,67\%. (2) Pemahaman mahasiswa tentang senyawa metabolit sekunder sebagai insektisida nabati dapat dilihat dengan hasil belajar yang diperoleh dengan persentase mahasiswa tuntas sebesar 77,27\% dan mahasiswa tidak tuntas sebesar $22,72 \%$.

Perlu dilakukan penelitian lebih lanjut untuk penerapan proses pembelajaran berbasis riset tidak hanya diterapkan pada materi isolasi dan karakterisasi senyawa tetapi dapat diterapkan pada semua materi.

\section{DAFTAR PUSTAKA}

Alade, Oluwatomi M., \& Angela, C. Ogbo. (2014). A Comparative Study of Chemistry Students' Learning Styles Preferences in Selected Public and Private School in Lagos Metropolis. Journal of Research \& Method in Education 4(1):45-53.

Arivoli, S., Samuel, Tennyson. (2013). Antifeedant activity, developmental indices and morphogenetic variations of plant extracts against Spodoptera litura (Fab) (Lepidoptera:Noctuidae). Journal of Entomology and Zoology Studies 1(4):87-96.

Biradar, Sanjay R., Rachetti, Bhagyashri D. (2016). Qualitative and Quantitative Analysis of Micropropagated Centella asiatica L. Journal of Pharmacy 6(2):72-76.

Blume, Stefan. (2015). Die Lernfabrik-Researchbased Learning for Sustainable Production Engineering. Procedia 32: 126-131.

Gupta, Sudhakar., Harpreet, Singh., Monika, Gupta. (2017). Influence of Ethanol Leaf Extract of Nerium oleander on the Life-Table Characteristics and Developmental Stages of Paederus fuscipes.

Harborne, J.B. (1987). Metode Fitokimia (Penerjemah Kosasih Padmawinata dan Iwang Soediro). Bandung: ITB.

Isman, M. B. (2000). Plant Essential Oils for Pest and Disease Management. Crop Protection 19(8-10):603-608.

Isnawati, Rina,. Murni, Nelfita,. (2015). Uji Daya Bunuh Ekstrak Daun Nerium oleander L. 
Terhadap Larva Nyamuk Aedes aegypti dan Culex quinquefasciatus. Jurnal Vektor Penyakit 9(2): 59-64.

Na'imah, Nur Jannatu, Supartono., Sri, Wardani. (2015). Penerapan Pembelajaran Berbasis Proyek Berbantuan E-Learning Untuk Meningkatkan Hasil Belajar Siswa. Jurnal Inovasi Pendidikan Kimia 9(2):1566-1574.

Purwanto, Ngalim. (2009). Evaluasi Hasil Belajar. Yogyakarta: Pustaka Pelajar.

Sarwar, Muhammad., Salman, Muhammad. (2015). Insecticides Resistance in Insect Pests or Vectors and Development of Novel Strategies to Combat Its Evolution. International Journal of Bioinformatics and Biomedical Engineering 1(3):344-351.

Siahaya, V. G., dan R. Y. Rimthe. (2014). Uji Ekstrak Daun Pepaya (Carica papaya) Terhadap Larva Plutella xylostella
(Lepidoptera: Plutellidae). Jurnal Ilmu Budidaya Tanaman 3(2):112-116.

Sudjana, Nana. (2011). Dasar Pembelajaran dan Pengajaran. Jakarta: Rineka Cipta

Sugiyono. (2014). Metode Penelitian Pendidikan. Bandung: Alfabeta.

Sutanto, Rachman. (2002). Pertanian Organik. Yogyakarta: Kanisius.

Widayati, Diah Tri., Djoko, L., Edia, R., Gentur, S., Harsono., Retno, P. S., Sajarwa. (2010). Pedoman Umum Pembelajaran Berbasis Riset (PUPBR). Yogyakarta: Universitas Gadjah Mada.

Zibbu, Garima., Batra, Amla. (2010). A Review on Chemistry and Pharmacological Activity of Nerium oleander L. Journal of Chemical and Pharmaceutical Research 2(6):351-358. 